\title{
Fruit and Hormones Influence Flowering of Apple. II. Effects of Hormones
}

\author{
Joann M. McLaughlin and Duane W. Greene \\ Department of Plant and Soil Sciences, University of Massachusetts, Amherst, MA 01003
}

Additional index words. MaIUs domestics, cytokinins, gibberellins, daminozide, return bloom

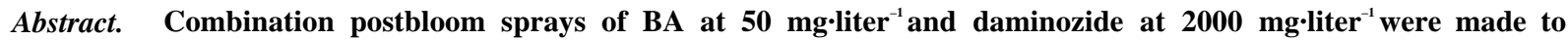
limbs of 'Early McIntosh' apple (Malus domestics Borkh.) where all of the flowers were either removed before full bloom or allowed to remain. BA and fruit removal increased return bloom, whereas daminozide bad no effect. No treatment had a consistent effect on spur leaf area. Repeat sprays of $\mathbf{G A}_{4+7}$ to 'Delicious' apple trees at full bloom (FB) $+5, \mathrm{FB}+14$, and FB +22 days reduced appendage development and flower bud formation on spurs. One spray of $\mathrm{GA}_{\mathrm{d}+7}$ at $150 \mathrm{mg} \cdot \mathrm{liter}^{-1}$ at $\mathrm{FB}+42$ days reduced appendage formation and the percentage of flowering spurs but not as effectively as earlier repeat sprays of $\mathbf{G A}_{4+7}$ at $50 \mathrm{mg} \cdot \mathrm{liter}^{-1}$. When BA at $150 \mathrm{mg} \cdot \mathrm{liter}^{-1}$ was $^{\mathrm{combined}}$ with the GA at $\mathrm{FB}+42$ days, appendage formation was increased but the reduction in flowering was not reversed. One BA spray at $50 \mathrm{mg} \cdot \mathrm{liter}^{-1}$ at $\mathrm{FB}+22$ days to 'McIntosh' trees increased the number of appendages formed in spurs, but return bloom was not influenced. Chemical names used: ( $N$-phenylmethyl) $-1 H$-purine-6-amine (BA); butanedioic acid mono (2, 2-dimethylhydrazide) (daminozide); gibberellins $A_{4}$ and $A_{7}\left(G A_{4+7}\right)$.
\end{abstract}

The presence of fruit inhibits flowering of apple (Fulford, 1966b). In some cultivars (biennial-bearing), flowering on shortened shoots or spurs is completely inhibited by fruit, whereas in other cultivars (annual-bearing), the presence of fruit usually allows enough flowers to be initiated for a consistent commercial crop (McLaughlin and Greene, 1991).

Chan and Cain (1967) demonstrated that the seeds of the fruit were the source of inhibition. Dennis and Nitsch (1966) identified two gibberellins in apple seeds, $\mathrm{GA}_{4}$ and $\mathrm{GA}_{7}$, and Marino and Greene (1981) found more gibberellins in spurs bearing fruit than in those lacking fruit. Gibberellin activity was higher in diffusates from fruit pedicels of biennially bearing cultivars than from those of annually bearing cultivars (Hoad, 1980). Fulford (1966a) proposed that flower initiation depended on the rate of initiation of nodes or appendages in the bourse bud of the spur. Failure to form flowers on a biennially bearing cultivar was associated with a specific decrease in the rate of initiation of appendages caused by the fruit; this decrease was not observed in annually bearing cultivars (Fulford, 1973). A clear link between gibberellin sprays that decrease flower bud formation and a reduction in the plastocron has not been clearly established.

Luckwill (1969) suggested the amount of flowering was determined by the balance of flower-promoting (cytokinins) and flower-inhibiting hormones (gibberellins). Evidence is strong that gibberellins from the seeds are the major source of the inhibitory influence of fruit on flowering (Hoad, 1978). In contrast, the involvement of cytokinins in flower initiation is less clear. BA can increase flower bud formation (McLaughlin and Greene, 1984; Ramirez, 1979). However, it is unclear whether the promotive effect is due to fruit thinning (Greene and Autio, 1989), counteracting the inhibitory effects of gibberellins (McLaughlin and Greene, 1984), or some other mechanism.

The purpose of this investigation was to further examine the influence of fruit on flowering and to determine the involvement of both gibberellins and a cytokinin in appendage initiation and flower, initiation.

Received for publication 6 Nov. 1989. Paper no. 2945 Massachusetts Agricultural Experiment Station, Univ. of Massachusetts at Amherst. This research was supported in part by the Experiment Station Project no. 609. The cost of publishing this paper was defrayed in part by the payment of page charges. Under postal regulations, this paper therefore must be hereby marked advertisement solely to indicate this fact.

\section{Materials and Methods}

Flowers, daminozide, and BA (Expt. 1). Four uniform limbs were selected on each of 12 mature 'Early McIntosh'/M.7 trees before bloom. Trees were grouped into six pairs, then one tree of each pair was sprayed to the drip point with daminozide at $2000 \mathrm{mg} \cdot \mathrm{liter}^{-1}$ at full bloom (FB) +4 days. Four limbs on each of the 12 trees were assigned randomly one of the following treatments: a) all flower clusters retained ( + flowers), no benzyladenine (BA); b) all flower clusters removed ( - flowers), no BA; c) - flowers, + BA; d) + flowers, + BA. Flowers were removed 9 days before $\mathrm{FB}$. BA was applied as a foliar spray at $50 \mathrm{mg} \cdot \mathrm{liter}^{-1}$ at $\mathrm{FB}+4$ and $\mathrm{FB}+26$ days. Treatments were replicated six times in a randomized block design with a split for the daminozide treatment. Six limbs on adjacent "off" year 'Early McIntosh' trees and six limbs on nearby fruiting mature 'McIntosh' trees were also selected for comparison with the growth regulator treatments.

Ten spurs on each tagged limb were collected at $\mathrm{FB}+5$, $+8,+13,+24,+32,+47,+61$, and +88 days. The leaves were removed and the spurs were stored in formalin : 70\% ethylene alcohol : acetic acid (FAA) (10:50:5, by volume) solution until dissection under a stereoscopic microscope. Two spur samples of the 10 that were collected from each of the six replications were selected and counted. At FB $+8,+13,+24$, and +32 days, 25 additional spurs were collected. The total leaf area per spur was determined using a LI-COR Model 3100 Area Meter (LI-COR, Lincoln, Neb.). Return bloom on tagged limbs was determined the following spring by counting the total number of spurs and the number of blossom clusters and then calculating the percentage of flowering spurs.

Gibberellins and BA (Expt. 2). Before bloom in 1985, 24 tenyear-old 'Double Red Delicious'/M.26 trees were selected and divided into six groups of four trees each. Four treatments were applied to a single tree in each group: 1) control, no hormone treatment; 2) $\mathrm{GA}_{4+7}, 50 \mathrm{mg} \cdot \mathrm{liter}^{-1}$ at $\mathrm{FB}+5,+14$, and +22 days; 3) $\mathrm{GA}_{4+7}, 150 \mathrm{mg} \cdot \mathrm{liter}^{-1}$ at $\mathrm{FB}+42$ days; and 4) $\mathrm{GA}_{4+7}$, $150 \mathrm{mg} \cdot \mathrm{liter}^{-1}$, and $\mathrm{BA}, 150 \mathrm{mg} \cdot \mathrm{liter}^{-1}$, at $\mathrm{FB}+42$ days. The surfactant Buffer-X, at 0.0170 was added to all growth regulator treatments. Treatments were replicated six times and arranged in a randomized complete-block design. Five spurs per tree from treatments 1 and 2 were collected at FB $+22,+29$, and +65 days and the number of leaf-like appendages in the buds were counted. Return bloom for 1986 was estimated by collecting 25 
spurs per limb and dissecting them to determine the percentage of spurs that had initiated flowers. Return bloom was further evaluated by counting the total number of blossom clusters on two tagged limbs per tree.

Two limbs on six mature 'Rogers McIntosh'/M.7 trees were selected for uniform bloom and vigor before bloom. One limb per tree was sprayed with BA at $100 \mathrm{mg} \cdot \mathrm{liter}^{-1}$ at $\mathrm{FB}+22$ days and the second limb served as the untreated control. Treatments were arranged in a randomized complete-block design with six replications. Five spurs were collected and two were initially dissected for anatomical evaluation at FB +29 and +65 days. Return bloom was determined by counting the number of blossom clusters on tagged limbs before bloom.

Square root transformations were performed on all counts of appendages. Treatment means within period and cultivar were separated by Duncan's multiple range test at $P=0.05$ using a pooled interaction and main factor error term for period, and a whole plot error term for bloom. In Expt. 1, daminozide effects on the number of appendages, return bloom, leaves, and leaf development were not significant and these data were combined with nondaminozide treatments. The data were then analyzed for the effects of BA.

\section{Results}

Appendage formation was not consistently influenced by treatments until 24 days after FB (Table 1). Differences that existed among treatments at $\mathrm{FB}+5$ and $\mathrm{FB}+8$ days were no longer observed at FB +13 days. By FB +24 days, spurs on limbs with or without fruit ( + or - flowers) and treated with BA had more appendages than the + fruit treatment, whereas spurs on limbs where flowers were removed had a similar number of appendages as spurs on the + flowers limbs. At FB +32 days, all treatments had more appendages than the + flowers treatment, and this continued for the remainder of the measurement period. Spurs sampled at FB +61 days from the - flowers + BA treatment had more appendages than those from the - flower and the + flower + BA treatments, and this continued to the end of the measurement period. Similarly, at FB +88 days, the - flower treatment had more appendages than the + flower + BA treatment. "Off" year spurs had a similar number of appendages as the + flower treatment until FB +32 days.
Subsequently, "off” year spurs began initiating appendages more rapidly than the + flower treatment.

Increased appendage number did not alwavs result in increased return bloom(TabIe 1). Increases in appendage count were associated with increases in return bloom on limbs where flowers had been removed (+ and - BA treatments). BA increased appendage formation on limbs with fruit but there was no increase in return bloom. BA was able to substantially increase return bloom only when no fruit were present on the spur.

No treatment had a consistent effect on leaf area (Table 2). However, BA increased the number of leaves per spur regardless of the presence of fruit. "Off" year spurs had a much higher leaf area per spur throughout the measurement period than any of the other treatments.

Seventeen days after the initial $\mathrm{GA}_{4+7}$ application, at $\mathrm{FB}+22$ days, $\mathrm{GA}_{4+7}$ had slowed appendage formation on fruit-bearing spurs of 'Delicious' and this reduction persisted throughout the examination period to $\mathrm{FB}+65$ days (Table 3). Late $\mathrm{GA}_{4+7}$ application at $\mathrm{FB}+42$ days also reduced appendage formation at $\mathrm{FB}+65$ days. Addition of $\mathrm{BA}$ to the late $\mathrm{GA}_{4+7}$ application not only reversed the inhibitory effect of the appendage formation but it also increased appendage formation above that recorded on the control trees. There was no difference between the number of appendages on nonbearing limbs of + or $-\mathrm{GA}_{4+7}$ treatments. Both early and late $\mathrm{GA}_{4+7}$ sprays reduced flower bud formation on spurs (percent floral spurs), although total bloom on the limbs treated late with $\mathrm{GA}_{4+7}$ was not reduced. Even though the reduction of appendage initiation was similar on early and late $\mathrm{GA}_{\mathrm{d}+7}$ sprays, the early sprays caused a greater reduction in flowering on spurs. The addition of BA did not increase the percentage of flowering spurs over that of the late $\mathrm{G} \mathrm{A}_{4+7}$ application. BA increased appendage formation on 'McIntosh' but only on the + flower + BA treatment at FB +65 days and this was not followed by an increase in the amount of return bloom.

\section{Discussion}

There is considerable evidence that daminozide can increase flower bud formation. However, daminozide did not increase return bloom on heavily bearing 'Golden Delicious' (McLaughlin and Greene, 1984), on biennially bearing 'Miller's

Table 1. Effects of fruit and growth regulators on the number of appendages on spurs of 'Early McIntosh' apple trees. ${ }^{2, y, x}$

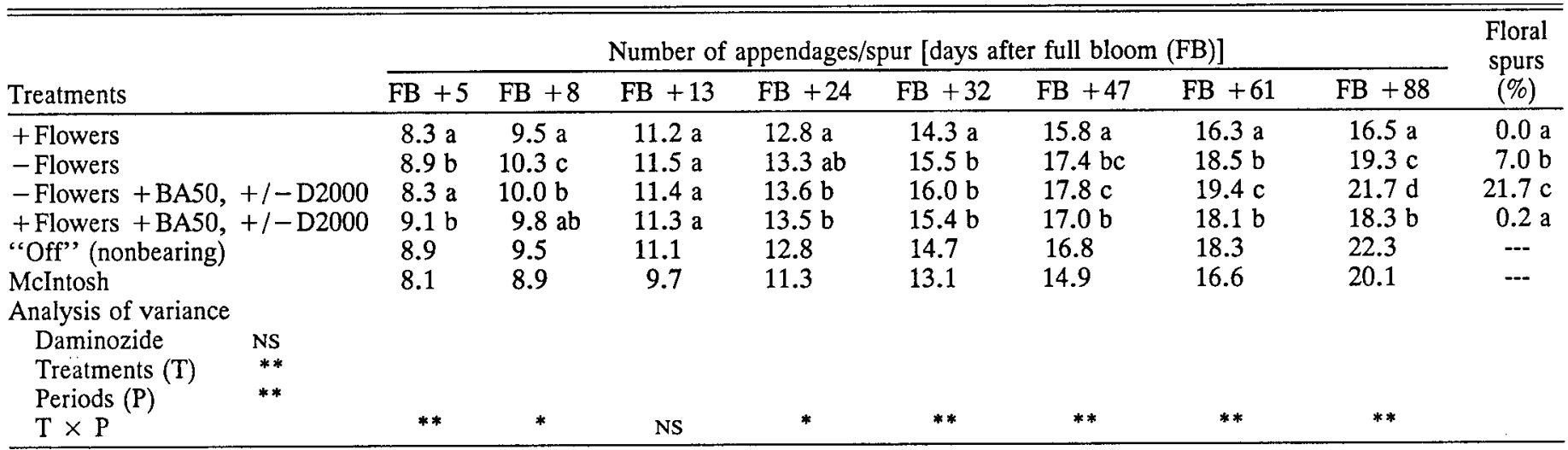

${ }^{7}$ Mean separation within columns by Duncan's multiple range test, $P=0.05$.

yDaminozide (D) was applied at $2000 \mathrm{mg} \cdot \mathrm{liter}^{-1}$ at $\mathrm{FB}+4$ days. Benzyladenine (BA) was applied at $50 \mathrm{mg} \cdot \mathrm{liter} \mathrm{r}^{-1}$ with $0.01 \% \mathrm{Buffer}-\mathrm{X}$ at $\mathrm{FB}$ +4 and 26 days. Flowers were removed 9 days prior to full bloom.

'Data are mean of 24 observations.

$* *, *, N s$ Significant at $P=0.01$ or 0.05 or nonsignificant, respectively. 
Table 2. Effects of flower removal and growth regulators on early leaf development of spurs of 'Early Mcintosh' apple trees..$^{z, y, x}$

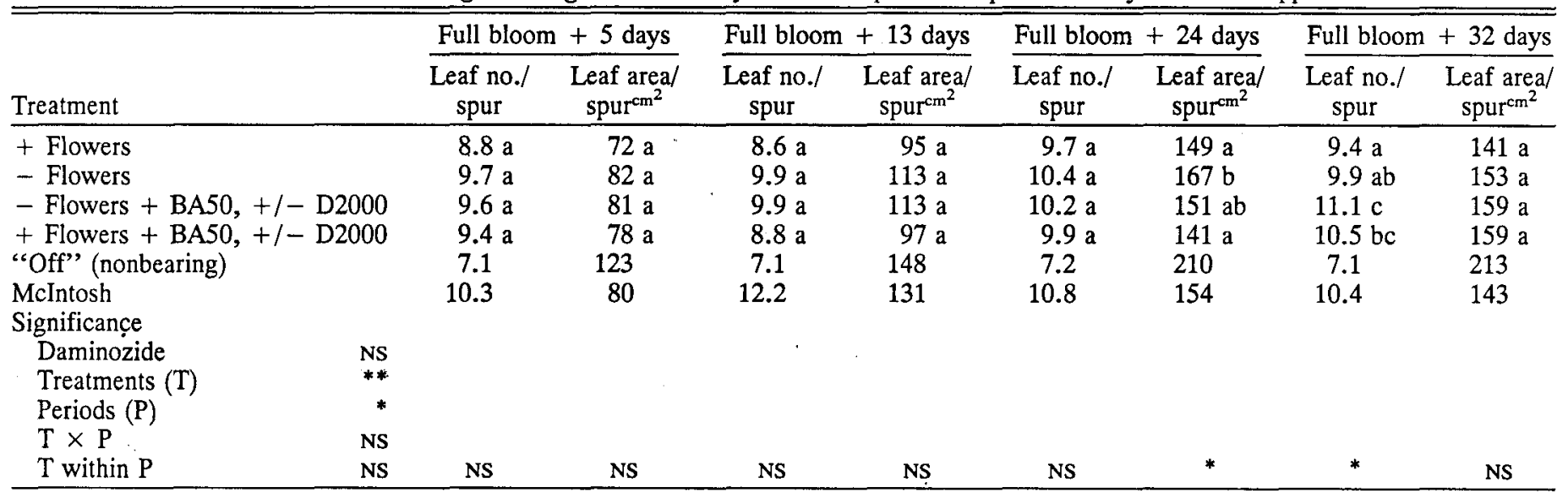

${ }^{z}$ Mean separation within columns, Duncan's Multiple Range Test, $P=0.05$.

yaminozide (D) was applied at $2000 \mathrm{mg} \cdot \operatorname{liter}^{-1}$ at $\mathrm{FB}+4$ days. Benzyladenine (BA) was applied at $50 \mathrm{mg} \cdot \mathrm{liter}{ }^{-1}$ with $0.01 \%$ Buffer-X at $\mathrm{FB}+4$ and 26 days. Flowers were removed 9 days prior to full bloom.

'Data are means of 50 observations.

${ }_{* *, *, N S S i g n i f i c a n t}$ at $P=0.01$ or 0.05 , or nonsignificant, respectively.

Table 3. Influences of growth regulators on the number of appendages and return bloom on spurs of 'Delicious' and 'McIntosh' apple trees. ${ }^{2 . x, w w}$

\begin{tabular}{|c|c|c|c|c|c|}
\hline \multirow{2}{*}{$\begin{array}{l}\text { Cultivar and } \\
\text { Treatment } \\
\end{array}$} & \multicolumn{3}{|c|}{$\begin{array}{c}\text { Appendages/spur } \\
\text { Days after full bloom (FB) }\end{array}$} & \multirow{2}{*}{$\begin{array}{c}\text { Floral } \\
\text { spurs } \\
(\%)\end{array}$} & \multirow{2}{*}{$\begin{array}{l}\text { Blossom clusters/ } \\
\mathrm{cm} \text { limb circumf. }\end{array}$} \\
\hline & $\mathrm{FB}+22$ & $\mathrm{FB}+29$ & $\mathrm{FB}+65$ & & \\
\hline \multicolumn{6}{|l|}{ Delicious } \\
\hline+ Fruit & $10.1 b^{y}$ & $11.4 \mathrm{~b}$ & $16.5 \mathrm{~b}$ & $67.0 \mathrm{c}$ & $6.7 \mathrm{~b}$ \\
\hline nonbearing & $11.8 \mathrm{c}$ & $13.6 \mathrm{c}$ & $17.5 \mathrm{c}$ & -.- & --- \\
\hline + Fruit + GA early & $9.4 \mathrm{a}$ & $10.8 \mathrm{a}$ & $15.1 \mathrm{a}$ & $7.3 \mathrm{a}$ & $1.0 \mathrm{a}$ \\
\hline nonbearing + GA early & $11.8 \mathrm{c}$ & $13.6 \mathrm{c}$ & $17.5 \mathrm{c}$ & -- & -- \\
\hline+ Fruit + GA late & -- & $-\cdots$ & $15.3 \mathrm{a}$ & $46.0 \mathrm{~b}$ & $4.5 \mathrm{ab}$ \\
\hline+ Fruit + GA late + BA late & --- & --- & $17.3 \mathrm{c}$ & $32.7 \mathrm{~b}$ & $5.8 \mathrm{~b}$ \\
\hline \multicolumn{6}{|l|}{ McIntosh } \\
\hline+ Fruit & --- & 11.9 a & $16.8 \mathrm{a}$ & --- & $11.0 \mathrm{a}$ \\
\hline+ Fruit + BA & -- & $12.1 \mathrm{a}$ & $18.0 \mathrm{~b}$ & $\cdots$ & $8.8 \mathrm{a}$ \\
\hline
\end{tabular}

${ }^{2} \mathrm{GA}$ early applied at $\mathrm{FB}+5,+14$, and +22 days at $50 \mathrm{mg} \cdot \mathrm{liter}^{1}$. GA and BA were applied at FB +42 days at $150 \mathrm{mg} \cdot$ liter $^{1}$. All sprays included $0.01 \%$ Buffer-X.

${ }^{\mathrm{x}} \mathrm{BA}$ was applied at $\mathrm{FB}+22$ days at $100 \mathrm{mg} \cdot \operatorname{liter}^{-1}$ with $0.01 \%$ Buffer-X.

'Mean separation within columns and cultivars by Duncan's multiple range test, $P=0.05$.

wata are; means of 12 observations.

Seedling' (Ramirez, 1979), or on biennially bearing 'Early McIntosh' in this experiment (Table 1). It appears, then, that daminozide may be insufficient alone to increase flowering on biennial cultivars carrying a very heavy crop load. Daminozide can increase flower bud formation on annual bearing cultivars where crop load is not excessive, but it had no effect on the rate of appendage initiation (Luckwill and Silva, 1979). Therefore, the lack of effect of daminozide on increasing flowering and appendage formation on the very biennial cultivar 'Early McIntosh' was expected.

BA application and fruit removal appear to have had a similar effect on initially preventing a reduction in the number of appendages. Gibberellins diffuse from the flowers/fruit into the spur (Marino and Greene, 1981) and more gibberellins move out of fruit of biennially bearing cultivars than out of annual cultivars (Hoad, 1978). Gibberellins from the seed may be interfering with the movement of cytokinins, thus reducing the amount available for meristematic activity in the bourse bud. Ramirez (1979) has shown that movement of labeled kinetin from the leaves into the bourse bud is less on biennially than annually bearing cultivars.

The period for flower initiation in 'Early McIntosh' appeared to be between $\mathrm{FB}+61$ and $\mathrm{FB}+88$ days, or 13 July to 9 Aug. Appendage 19 would be the last true leaf and appendage 20 would be the first bract of the inflorescence. The apex of many bourse buds in the - flowers + BA treatment remained active after $\mathrm{FB}+61$ days to produce 20 appendages and form flowers (McLaughlin and Greene, 1984). The earlier initiation of flowers on this treatment in contrast of "off" year spurs is further evidence that a specific rate of initiation of appendages may not be the determining factor in flower initiation, as previously suggested (Fulford, 1966a). Instead, the ability to continue to initiate appendages at the time of initiation of the first bract may be more important than the rate at which appendages are formed. Appendage formation in buds on spurs bearing a fruit ceased during this critical time of flower bud formation, whereas the apex of the bourse bud remained active and produced flowers on spurs that did not carry a fruit (Table 1). 
The presence of developing flowers even for a short period was sufficient to later reduce the rate of appendage initiation and the amount of return bloom. This result is in agreement with the suggestion of Marino and Greene (1981). However, leaving flowers or fruit on the spur for a longer time resulted in greater inhibition. There was a greater reduction in both bloom and the number of appendages on spurs carrying fruit (+ and - BA), indicating, as previously observed on 'Golden Delicious' (McLaughlin and Greene, 1984), that there is a progressive inhibitory effect the longer fruit remain attached to the spur.

The major GAs that diffuse from the seeds into the spur tissue are $\mathrm{GA}_{4}$ and $\mathrm{GA}_{7}(\mathrm{Hoad}, 1980)$ and both are produced by the seeds of annual and biennial cultivars (Pharis and King, 1985), but it is not known what amounts of the individual GAs are produced. There is strong evidence that it is $\mathrm{GA}_{7}$ rather than $\mathrm{GA}_{4}$ that inhibits flower bud formation (Looney et al., 1985; Tromp, 1982). We speculate that $\mathrm{GA}_{7}$ may be the dominant gibberellin present or translocated from biennially bearing cultivars.

Roots generally are acknowledged to be a major source of cytokinins and they maybe detected in the apple in the xylem (Luckwill and Whyte, 1968). However, leaves are required for flower initiation and they are also a major source of cytokinins (Wareing et al., 1976). Leaves provide photosynthate to the surrounding fruit and tissues that may, in turn, promote flowering. It has been previously shown that 190 to $230 \mathrm{~cm}^{2}$ of leaf area was required for flower bud initiation to occur on 'Golden Delicious' (Hansen, 1969). Delayed and reduced leaf expansion of 'Early McIntosh' (Table 1) may then be a factor in inhibiting flower bud formation by lowering the amount of hormones or photosynthates available for growth of the bourse bud.

Flower removal on "on" year spurs did not increase the amount of leaf area similar to that of "off" year spurs. The differences may be partially attributable to development of buds the previous season. When flower initiation does not occur, the apex may stop initiating appendages, but development of existing appendages does not cease. Without the presence of developing flowers, appendages" appear to develop more fully. The innermost appendages on vegetative spurs were much larger and appeared as miniature leaves on which venation patterns could be seen. At the same time, the primary leaves of buds that had initiated flowers appeared smaller and not nearly as well-differentiated.

Previous reports have failed to show that $\mathrm{GA}_{3}$ application reduced the rate of appendage initiation (Fulford, 1973; Luckwill and Silva, 1979). However, in this investigation, bourse buds subtending fruit and sprayed with $\mathrm{GA}_{4+7}$ either early or late had fewer appendages and less return bloom than bourse buds not sprayed with $\mathrm{GA}_{4+7}$ (Table 2). $\mathrm{GA}_{4+7}$ applications to spurs lacking fruit did not reduce the number of appendages. This result supports the suggestion that other factors may be involved in regulating flower bud formation (Fulford, 1973; Looney and Pharis, 1986).

\section{Literature Cited}

Chan, B. and J. Cain. 1967. The effect of seed formation on subsequent flowering in apple. Proc. Amer. Soc. Hort. Sci. 91:63-68.

Dennis, F. G., Jr. and J.P. Nitsch. 1966. Identification of gibberllins A4 and A7 in immature apple seeds. Nature (London) 211:781-782.

Fulford, R.M. 1966a. The morphogenesis in apple buds. III. The inception of flowers. Arm. Bet. 30:207-219.

Fulford, R.M. 1966b. The morphogenesis of apple buds. IV. The effect of fruit. Ann. Bet. 30:597-606.

Fulford, R.M. 1973. Flower initiation: effect of gibberellin sprays. Rpt. E. Mailing Res. Sta. 1973. p. 93.

Greene, D.W. and W.R. Autio. 1989. Evaluation of benzyladenine as a chemical thinner on McIntosh apples. J. Amer. Soc. Hort. Sci. 114:68-73.

Hansen, P. 1969. 14-C studies on apple trees. IV. Photosynthate consumption in fruits in relation to the leaf-fruit position. Physiol. Plant. 22:186-198.

Hoad, G.V. 1978. The role of seed derived hormones in the control of flowering in apple. Acts Hort. 80:93-103.

Hoad, G.V. 1980. Growth regulators, endogenous hormones and flower initiation in apple. Rpt. Long Ashton Res. Sta. 1979. p. 199-206.

Looney, N.E. and R.D. Pharis. 1986. Gibberellins and reproductive development of tree fruits and grapes. Acts Hort. 179:59-71.

Looney, N. E., R.P. Pharis, and M. Noms. 1985. Promotion of flowering in apple trees with gibberellin A4 and C-3 epi-gibberellin A4. Planta 165:292-294.

Luckwill, L.C. 1969. The control of growth and fruitfulness of apple trees, p. 237-254. In: L.C. Luckwill and C.V. Cutting (eds.). Physiology of tree crops. Academic New York.

Luckwill, L.C. and J.M. Silva. 1979. The effects of daminozide and gibberellic acid on flower initiation, growth, and fruiting of apple CV. Golden Delicious. J. Hort. Sci. 54:217-223.

Luckwill, L.C. and P. Whyte. 1968. Hormones in the xylem sap of apple trees. S.C.I. Monogr. 31:87-101.

Marine, F. and D.W. Greene. 1981. Involvement of gibberellins in the biennial bearing of 'Early McIntosh' apples. J. Amer. Soc. Hort. Sci. 106:593-596.

McLaughlin, J.M. and D.W. Greene. 1984. Effects of BA, GA4 + 7, and daminozide on fruit set, fruit quality, vegetative growth, flower initiation, and flower quality of' Golden Delicious' apple. J. Amer. Soc. Hort. Sci. 109:34-39.

McLaughlin, J.M. and D.W. Greene. 1991. Fruit and hormones influence flowering of apple. I. Effect of cultivar. J. Amer. Soc. Hort. Sci. 116(3):446-449.

Pharis, R.P. and R.W. King. 1985. Gibberellins and reproductive development in seed plants. Annu. Rev. Plant Physiol. 36:517-568.

Ramirez, H. 1979. Effects of growth substances on some physiological processes in apple in relation to flower initiation. $\mathrm{PhD}$ Diss., Univ. of Bristol.

Tromp, J. 1982. Flower bud formation in apple as influenced by various gibberellins. J. Hort. Sci. 57:277-282.

Wareing, P. F., R. Horgan, I.E. Henson, and W. Davis. 1976. Cytokinin relations in the whole plant, p. 147-153. In: P.E. Pilet (cd.). Plant growth regulation. Springer-Verlag, New York. 